\title{
Regenerative Nodular Hyperplasia of the Liver Related to Chemotherapy: Impact on Outcome of Liver Surgery for Colorectal Metastases
}

\author{
Dennis A. Wicherts, $\mathrm{MD}^{1,4}$, Robbert J. de Haas, $\mathrm{MD}^{1,4}$, Mylène Sebagh, $\mathrm{MD}^{2}$, Oriana Ciacio, $\mathrm{MD}^{1}$, \\ Francis Lévi, MD, $\mathrm{PhD}^{3,6,7}$, Bernard Paule, $\mathrm{MD}^{1,3}$, Sylvie Giacchetti, $\mathrm{MD}^{3,8}$, Catherine Guettier, $\mathrm{MD}, \mathrm{PhD}^{2,5,7}$, \\ Daniel Azoulay, MD, PhD ${ }^{1,9}$, Denis Castaing, $\mathrm{MD}^{1,5,7}$, and René Adam, MD, $\mathrm{PhD}^{1,5,7}$ \\ ${ }^{1}$ Centre Hépato-Biliaire, AP-HP Hôpital Paul Brousse, Villejuif, France; ${ }^{2}$ Department of Pathology, AP-HP Hôpital Paul \\ Brousse, Villejuif, France; ${ }^{3}$ Department of Medical Oncology, AP-HP Hôpital Paul Brousse, Villejuif, France; \\ ${ }^{4}$ Department of Surgery, University Medical Center Utrecht, Utrecht, The Netherlands; ${ }^{5}$ Inserm, Unité 785, Villejuif, \\ France; ${ }^{6}$ Laboratoire 'Rythmes biologiques et cancers' Unité 776, Inserm, Villejuif, France; ${ }^{7}$ Université Paris-Sud, UMR-S \\ 785, Villejuif, France; ${ }^{8}$ Department of Medical Oncology, AP-HP Hôpital Saint-Louis, Paris, France; ${ }^{9}$ Inserm, Unité 1004, \\ Villejuif, France
}

\begin{abstract}
Background. Regenerative nodular hyperplasia (RNH) represents the end-stage of vascular lesions of the liver induced by chemotherapy. The goal was to evaluate its incidence and impact on the outcome of patients resected for colorectal liver metastases (CLM).

Methods. Patients who underwent hepatectomy for CLM after six cycles or more of first-line chemotherapy, between January 1990 and November 2006, were included. Detailed histopathologic analysis of the nontumoral liver was performed according to a standard format.

Results. From a cohort of 856 resected patients at our institution, $771(90 \%)$ received preoperative chemotherapy. Of these, 146 fulfilled the selection criteria and were included: $24(16 \%)$ received 5-fluorouracil (5-FU) and leucovorin (LV) alone, 92 (63\%) had 5-FU/LV and oxaliplatin, $18(12 \%)$ had 5-FU/LV and irinotecan, and 12 $(8 \%)$ were treated by $5-\mathrm{FU} / \mathrm{LV}$, oxaliplatin, and irinotecan. RNH occurred in 22 of 146 patients (15\%). Twenty of these patients $(91 \%)$ received oxaliplatin, of whom six (30\%) had chronomodulated therapy. Patients treated by oxaliplatin more often had RNH compared with oxaliplatin-naïve patients (22 vs. 4\%). Although operative
\end{abstract}

(C) The Author(s) 2010. This article is published with open access

at Springerlink.com

First Received: 20 April 2010;

Published Online: 26 October 2010

R. Adam, MD, PhD

e-mail: rene.adam@pbr.aphp.fr mortality was nil, the presence of RNH was associated with increased postoperative hepatic morbidity (50 vs. 29\%). Elevated preoperative gamma-glutamyltransferase (GGT) $(>80 \mathrm{U} / \mathrm{L} ;>1 \mathrm{~N})$ and total bilirubin levels $(>15 \mu \mathrm{mol} / \mathrm{L}$; $>1 \mathrm{~N}$ ) were independent predictors of RNH.

Conclusions. Patients with CLM who receive preoperative oxaliplatin have an increased risk of RNH and associated postoperative morbidity. Increased serum GGT and bilirubin are useful markers to predict the presence of RNH.

During recent years, the intensity of preoperative systemic chemotherapy for patients with colorectal liver metastases (CLM) has increased significantly. Patients with unresectable metastatic disease frequently receive prolonged chemotherapy treatment in an attempt to convert them to resectability. With this approach, long-term survival can be achieved when liver resection becomes feasible after tumoral downsizing. ${ }^{1}$ In addition, neoadjuvant chemotherapy is applied for resectable liver metastases to facilitate margin-free resections, and this approach has shown recently to improve progression-free survival after hepatectomy. ${ }^{2,3}$

Our group and others have reported a relationship between the use of preoperative chemotherapy and histopathologic changes of the nontumoral liver with consequently an increased risk of perioperative morbidity. ${ }^{3-11}$ This mainly concerns the prolonged use of oxaliplatin and associated vascular lesions. However, close evaluation of direct relations between specific vascular lesions and postoperative outcome 
remains limited (Table 1)., ${ }^{3,6-15}$ Only three studies have correlated specific chemotherapy-related vascular changes in the nontumoral liver with an increased intraoperative transfusion rate or longer hospital stay. ${ }^{8-10}$

Regenerative nodular hyperplasia $(\mathrm{RNH})$ is considered the end-stage of vascular lesions induced by chemotherapy, but its effect on the outcome of hepatic resection for colorectal metastases remains unclear. However, with the increasing indications of preoperative chemotherapy, especially oxaliplatin, RNH is observed more frequently, necessitating an evaluation of its consequences. Furthermore, with the high incidence of recurrences observed in patients resected of CLM, repeat hepatectomies are increasingly performed. ${ }^{16-18}$ Knowledge concerning the consequences of RNH, as well as its potential to regress, is crucial in evaluating the risks of repeat surgery with the continuing administration of chemotherapy.

In this study, we evaluated the incidence of RNH and its impact on postoperative outcome in patients resected of CLM. In addition, we assessed the evolution of RNH by analyzing the pathological specimens of patients submitted to repeat hepatectomy.

\section{PATIENTS AND METHODS}

\section{Patients}

From January 1990 to November 2006, 856 consecutive patients underwent partial hepatectomy for colorectal metastases at our institute; $771(90 \%)$ of these patients were treated by preoperative chemotherapy, whereas 85 patients $(10 \%)$ underwent hepatic resection without preoperative chemotherapy treatment. Of all 771 patients treated by preoperative chemotherapy, this study focused only on patients who received six or more cycles of firstline therapy. In addition, patients treated with preoperative intra-arterial chemotherapy were excluded.

\section{Preoperative Chemotherapy}

Chemotherapy was most often administered before surgery for patients with initially unresectable metastases. Technical unresectability was defined as the inability to completely resect all metastases while leaving at least 30\% of normal liver parenchyma, resulting from a multinodular

TABLE 1 Review of publications evaluating the effect of preoperative chemotherapy and hepatic chemotoxicity on short-term outcome after resection of colorectal liver metastases

\begin{tabular}{|c|c|c|c|c|c|}
\hline Author & Year & $\begin{array}{l}\text { No. of } \\
\text { patients }^{\mathrm{a}}\end{array}$ & $\begin{array}{l}\text { Type of } \\
\text { chemotherapy }\end{array}$ & $\begin{array}{l}\text { Related histology } \\
\text { nontumoral liver }\end{array}$ & Short-term perioperative outcome \\
\hline \multicolumn{6}{|c|}{ Studies of no effect } \\
\hline Parikh $^{12}$ & 2003 & 61 & Irinotecan & Steatosis & Unaffected \\
\hline Hewes $^{13}$ & 2007 & 46 & Miscellaneous ${ }^{\mathrm{b}}$ & None & Unaffected \\
\hline \multirow[t]{2}{*}{ Pawlik $^{14}$} & 2007 & 153 & Oxaliplatin & Sinusoidal dilatation & Unaffected \\
\hline & & & Irinotecan & Steatosis/steatohepatitis & Unaffected \\
\hline Scoggins ${ }^{15}$ & 2009 & 112 & Miscellaneous $^{\mathrm{c}}$ & None & Unaffected \\
\hline \multicolumn{6}{|c|}{ Studies of effect-outcome related to chemotherapy } \\
\hline Karoui $^{6}$ & 2006 & 45 & Miscellaneous $^{\mathrm{d}}$ & Sinusoidal dilatation & Increased morbidity \\
\hline Nordlinger $^{3}$ & 2008 & 151 & Oxaliplatin & Not analyzed & Increased morbidity \\
\hline \multicolumn{6}{|c|}{ Studies of effect—outcome related to liver histology } \\
\hline \multirow[t]{2}{*}{ Vauthey $^{7}$} & 2006 & 248 & Oxaliplatin & Sinusoidal dilatation & Unaffected \\
\hline & & & Irinotecan & Steatohepatitis & Increased 90-day mortality \\
\hline Aloia $^{8}$ & 2006 & 75 & Oxaliplatin & $\mathrm{HCN} / \mathrm{RNH}$ & Increased transfusion rate \\
\hline Mehta $^{9}$ & 2007 & 130 & Oxaliplatin & Sinusoidal dilatation & $\begin{array}{l}\text { Longer hospital stay and increased } \\
\text { transfusion rate }\end{array}$ \\
\hline Nakano $^{10}$ & 2008 & 90 & Oxaliplatin & Sinusoidal injury & $\begin{array}{l}\text { Longer hospital stay and increased } \\
\text { morbidity }\end{array}$ \\
\hline \multirow[t]{2}{*}{ Kandutsch $^{11}$} & 2008 & 50 & Oxaliplatin & Fibrosis & Increased transfusion rate \\
\hline & & & & Sinusoidal dilatation & Unaffected \\
\hline
\end{tabular}

$H C N$ hemorrhagic centrilobular necrosis, $R N H$ regenerative nodular hyperplasia

a Treated with preoperative chemotherapy

b 5-Fluorouracil and leucovorin alone or combined with oxaliplatin

c 5-Fluorouracil with various combinations of other agents

d 5-Fluorouracil and leucovorin alone or combined with oxaliplatin, irinotecan or both

e In patients who underwent major hepatectomy ( $\geq 3$ segments) 
tumor distribution, large tumor size, or a close relationship with major vascular or biliary structures. The presence of extrahepatic metastases determined oncological unresectability. The rationale to administer preoperative chemotherapy to patients with upfront resectable metastases was to assess tumor chemoresponsiveness and to facilitate margin-negative resections.

Response to chemotherapy was evaluated in a multidisciplinary meeting with surgeons, oncologists, and radiologists, and surgery was only performed when the overall strategy could result in complete intra- and extrahepatic tumor clearance.

\section{Liver Resection}

The goal of liver surgery was to resect completely all detectable lesions. Detailed inspection, palpation, and intraoperative ultrasound of the liver were routinely performed in each patient. Local ablation, portal vein embolization, and two-stage hepatectomy were used as described before to increase the possibility of radical tumor resection. ${ }^{19-21}$ General and local hepatic complications occurring within 2 months after surgery were recorded and classified. $^{22,23}$

\section{Histopathologic Examination}

Detailed histopathologic assessment of the nontumoral liver was performed by a single hepatobiliary pathologist, blinded for the information regarding preoperative chemotherapy and perioperative outcome. Liver tissue was analyzed according to a standard format previously described. ${ }^{8}$ Briefly, vascular lesions were categorized as sinusoidal alterations (vasodilatation and congestion), peliosis, hemorrhagic centrilobular necrosis $(\mathrm{HCN}), \mathrm{RNH}$, and veno-occlusive disease. The presence of macrovacuolar steatosis was graded as mild ( $<30 \%$ of hepatocytes), moderate $(30-60 \%)$, or severe $(>60 \%)$. Steatohepatitis included steatosis with signs of local inflammation and apoptotic hepatocytes. Fibrosis was divided into portal fibrosis, porto-portal fibrosis, septal fibrosis, and cirrhosis. Surgical necrosis also was noted.

\section{Repeat Surgery}

The development of recurrences was assessed by physical examination, serum CEA and CA 19.9 levels, and abdominal ultrasound at 4-month intervals after hepatectomy. CT imaging of the chest, abdomen, and pelvis was performed every 8 months. Repeat resection of intra- and/ or extrahepatic recurrences was only considered if it could be macroscopically complete. ${ }^{17}$ For patients who underwent repeat liver surgery, histopathologic examination of the nontumoral liver was performed in a similar way as described above to evaluate the evolution of initial lesions.

\section{Statistical Analysis}

All statistical analyses were performed using $\operatorname{SPSS}^{\circledR}$ software version 13.0 (SPSS Inc., Chicago, IL). Categorical data were reported as the number of patients with percentages and compared by the $\chi^{2}$ test. For continuous data, reported as means \pm standard deviation, the independent-samples $t$ test was used to compare groups. Logistic regression was done to define independent predictive factors of hepatic morbidity as well as preoperative predictive factors of RNH. Factors with $P \leq 0.10$ at univariate analysis were included. $P$ values $\leq 0.05$ were considered significant.

\section{RESULTS}

Of all 771 consecutively resected patients treated by preoperative chemotherapy, 155 received six or more cycles of first-line therapy, delivered by intravenous route. Due to an insufficient amount of nontumoral liver parenchyma available for histopathological analysis, 9 patients were excluded, resulting in a cohort of 146 patients (Fig. 1).

\section{Patient and Tumor Characteristics}

Included patients had a median age of 61 (range, 34-79) years and $76 \%$ presented with synchronous liver metastases (Table 2). Most patients (54\%) had $>3$ metastases at diagnosis with a median diameter of 40 (range, 6-160) $\mathrm{mm}$. Metastases were located in both liver lobes in $70 \%$ of patients and 20 patients (14\%) had concomitant extrahepatic disease.

\section{Preoperative Chemotherapy}

Chemotherapy was indicated for initially unresectable metastases in the majority of patients $(72 \%)$. Unresectability was related to multinodular disease (59\%), large tumor size (29\%), close vascular relationship (10\%), and extrahepatic disease (3\%). The remaining $28 \%$ of patients received preoperative chemotherapy for resectable disease. The median number of administered cycles for the total group was 8 (range, 6-21) and chemotherapy delivery was chronomodulated in $41 \%$ of patients. ${ }^{24}$ Twenty-four patients (16\%) received 5-fluorouracil (5-FU) and leucovorin $(\mathrm{LV})$ alone $(9.0 \pm 2.0$ cycles), 92 patients $(63 \%)$ had 5 -FU/LV and oxaliplatin ( $8.6 \pm 2.8$ cycles), 18 patients (12\%) had 5-FU/LV and irinotecan $(8.9 \pm 3.0$ cycles $)$, and 12 patients $(8 \%)$ were treated by $5-\mathrm{FU} / \mathrm{LV}$, oxaliplatin, and 
FIG. 1 Flowchart of patient selection

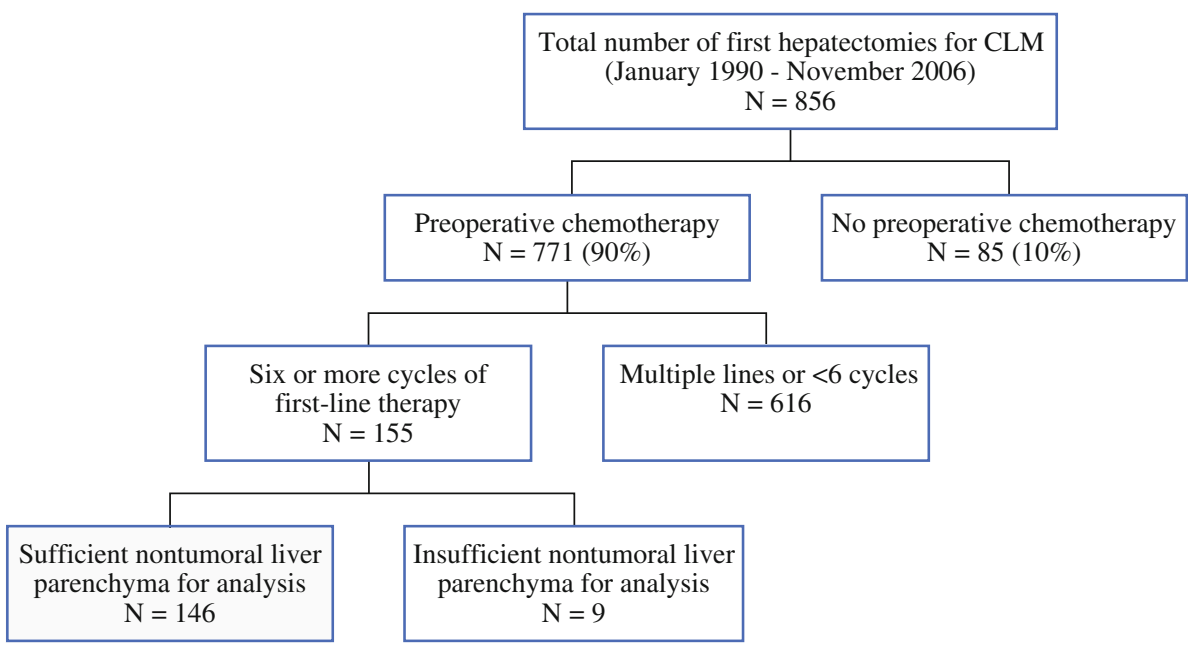

irinotecan $(9.6 \pm 3.6$ cycles). The number of chemotherapy cycles did not differ between different regimens $(P=0.70)$

\section{Hepatectomy Characteristics}

Major hepatectomies ( $\geq 3$ segments) were performed in $50 \%$ of patients (Table 2). Red blood cell transfusions were required in $41 \%$ of patients, of whom $94 \%$ needed more than 1 unit of blood. Postoperative morbidity occurred in $43 \%$ of patients and one patient (1\%) died within 60 days after surgery. Hepatic complications were classified as grade III or IV complications in $34 \%$ of patients. Median duration of hospital stay was 11 (range, 6-42) days.

\section{Nontumoral Liver Parenchyma}

Vascular liver lesions constituted the most frequent type of histopathological lesion and were present in 82 patients (56\%; Table 2). Peliosis was most often observed (31\%). RNH occurred in 22 of 146 patients $(15 \%)$ and was more frequent than sinusoidal alterations (11\%; Fig. 2). Of note, steatohepatitis occurred in only one patient (1\%).

\section{RNH Versus Non-RNH Patients}

Patients with RNH more often presented with $>3$ metastases at diagnosis compared with patients without RNH (78 vs. $50 \% ; P=0.03$; Table 3). Twenty RNH patients $(91 \%)$ preoperatively received 5-FU/LV and oxaliplatin $(9.2 \pm 2.6$ cycles). The two remaining patients were treated by 5-FU/LV and irinotecan (12 cycles; $\mathrm{N}=1)$ and 5-FU/LV, oxaliplatin, and irinotecan (6 cycles; $\mathrm{N}=1$ ). Chemotherapy was chronomodulated in six patients (27\%; all oxaliplatin). RNH occurred in $22 \%$ of patients treated by oxaliplatin compared with $4 \%$ of oxaliplatin-naïve patients $(P=0.003)$. The number of chemotherapy cycles was not increased in RNH patients compared with the control group $(9.1 \pm 2.7$ vs. $8.8 \pm 2.8$; $P=0.55)$.

RNH patients had lower platelet counts at hospital admission $\left(\leq 150 \times 10^{3} / \mu \mathrm{L}: 48\right.$ vs. $\left.17 \% ; P=0.002\right)$. Mean alkaline phosphatase, gamma-glutamyltransferase (GGT), and total bilirubin levels before surgery were higher in RNH patients (Table 3).

Major hepatectomies were performed in a similar percentage of patients with and without RNH (55 vs. 49\%, respectively; $P=0.64$; Table 3 ). None of the $\mathrm{RNH}$ patients died within 60 days postoperatively. However, hepatic complications occurred in 50\% of RNH patients compared with $29 \%$ of patients without RNH $(P=0.05)$. This difference was mainly caused by an increased incidence of biliary leaks (27 vs. $0 \%$ ).

\section{Uni- and Multivariate Analysis of Hepatic Morbidity}

Seven factors, including RNH, were associated with hepatic morbidity at univariate analysis (Table 4). However, only four factors were independent predictors at multivariate analysis: a preoperative platelet count of $<150 \times 10^{3} / \mu \mathrm{L}$, major hepatectomy, two-stage hepatectomy, and intraoperative red blood cell transfusion.

\section{Predictive Factors of RNH}

Multivariate logistic regression analysis identified elevated preoperative GGT $(>80 \mathrm{U} / \mathrm{L} ;>1 \mathrm{~N})$ and total bilirubin levels $(>15 \mu \mathrm{mol} / \mathrm{L} ;>1 \mathrm{~N})$ as independent factors predictive for the presence of RNH. Risk ratios were 6.6 (95\% confidence interval (CI), 2-21.4) for GGT $(P=0.002)$ and $3.3(95 \% \mathrm{CI}, 1.1-10.0)$ for total bilirubin $(P=0.04)$. 
TABLE 2 Characteristics of 146 included patients

\begin{tabular}{|c|c|}
\hline & $\begin{array}{l}\text { Chemotherapy group } \\
(\mathrm{N}=146)\end{array}$ \\
\hline \multicolumn{2}{|l|}{ Patients } \\
\hline Mean age \pm SD (yr) & $59.1 \pm 9.5$ \\
\hline Male/female ratio & $85(58 \%) / 61(42 \%)$ \\
\hline Mean body mass index $\pm \mathrm{SD}\left(\mathrm{kg} / \mathrm{m}^{2}\right)$ & $24.1 \pm 3.6$ \\
\hline Diabetes mellitus & $8(6 \%)$ \\
\hline \multicolumn{2}{|l|}{ Primary tumor } \\
\hline Colon/rectum & $114(79 \%) / 31(21 \%)$ \\
\hline \multicolumn{2}{|l|}{ T stage } \\
\hline $1 / 2$ & $19(17 \%)$ \\
\hline $3 / 4$ & $92(83 \%)$ \\
\hline \multicolumn{2}{|l|}{$\mathrm{N}$ stage } \\
\hline 0 & $43(38 \%)$ \\
\hline $1 / 2$ & $70(62 \%)$ \\
\hline \multicolumn{2}{|l|}{ Liver metastases diagnosis } \\
\hline Synchronous $^{\mathrm{a}}$ & $111(76 \%)$ \\
\hline \multicolumn{2}{|l|}{ Number } \\
\hline$\leq 3$ & $62(46 \%)$ \\
\hline$>3$ & $73(54 \%)$ \\
\hline Mean maximum size $\pm \mathrm{SD}(\mathrm{mm})$ & $45.2 \pm 28.6$ \\
\hline Bilobar & $102(70 \%)$ \\
\hline Mean CEA \pm SD $(n g / m L)$ & $293.2 \pm 643.1$ \\
\hline Concomitant extrahepatic disease & $20(14 \%)$ \\
\hline Extrahepatic resection & $11(58 \%)$ \\
\hline \multicolumn{2}{|l|}{ Hepatectomy } \\
\hline Major resection ( $\geq 3$ segments) & $73(50 \%)$ \\
\hline \multicolumn{2}{|l|}{ Resection type } \\
\hline Anatomical & $47(32 \%)$ \\
\hline Nonanatomical & $34(23 \%)$ \\
\hline Both & $65(45 \%)$ \\
\hline \multicolumn{2}{|l|}{ Vascular occlusion } \\
\hline No & $21(15 \%)$ \\
\hline Total pedicular & $73(54 \%)$ \\
\hline Vascular exclusion & $20(15 \%)$ \\
\hline Selective & $22(16 \%)$ \\
\hline \multicolumn{2}{|l|}{ Combined local ablation } \\
\hline No & $129(88 \%)$ \\
\hline Radiofrequency ablation & $10(7 \%)$ \\
\hline Cryotherapy & $7(5 \%)$ \\
\hline Portal vein embolization & $18(12 \%)$ \\
\hline Two-stage hepatectomy & $10(7 \%)$ \\
\hline \multicolumn{2}{|l|}{ Red blood cell transfusions } \\
\hline No & $78(59 \%)$ \\
\hline Yes & $54(41 \%)$ \\
\hline \multicolumn{2}{|l|}{ Postoperative outcome } \\
\hline Mortality ( $\leq 60$ days) & $1(1 \%)$ \\
\hline Morbidity & $63(43 \%)$ \\
\hline General complications ${ }^{\mathrm{b}}$ & $43(30 \%)$ \\
\hline
\end{tabular}

TABLE 2 continued

\begin{tabular}{|c|c|}
\hline & $\begin{array}{l}\text { Chemotherapy group } \\
(\mathrm{N}=146)\end{array}$ \\
\hline Hepatic complications & $47(32 \%)$ \\
\hline Biliary leak & $3(6 \%)$ \\
\hline Hemorrhage & $2(4 \%)$ \\
\hline Infected collection & $5(11 \%)$ \\
\hline Noninfected collection & $21(45 \%)$ \\
\hline Liver insufficiency ${ }^{23}$ & $8(17 \%)$ \\
\hline Combination & $8(17 \%)$ \\
\hline Relaparotomy & $5(3 \%)$ \\
\hline Drainage & $14(10 \%)$ \\
\hline Mean hospital stay \pm SD (days) & $12.9 \pm 5.9$ \\
\hline \multicolumn{2}{|l|}{ Nontumoral liver } \\
\hline Macrovacuolar steatosis $(\geq 30 \%)$ & $12(8 \%)$ \\
\hline Steatohepatitis & $1(1 \%)$ \\
\hline Fibrosis & $69(47 \%)$ \\
\hline Portal & $57(83 \%)$ \\
\hline Porto-portal & $11(16 \%)$ \\
\hline Septal & $0(0 \%)$ \\
\hline Cirrhosis & $1(1 \%)$ \\
\hline Vascular lesions $^{c}$ & $82(56 \%)$ \\
\hline Sinusoidal alterations ${ }^{\mathrm{d}}$ & $16(11 \%)$ \\
\hline Peliosis & $45(31 \%)$ \\
\hline $\mathrm{HCN}$ & $36(25 \%)$ \\
\hline RNH & $22(15 \%)$ \\
\hline Veno-occlusive disease & $18(14 \%)$ \\
\hline Surgical necrosis & $8(6 \%)$ \\
\hline
\end{tabular}

$S D$ standard deviation, $C E A$ carcinoembryonic antigen, $H C N$ hemorrhagic centrilobular necrosis, $R N H$ regenerative nodular hyperplasia

a Synchronous metastases were diagnosed before or within 3 months after resection of the primary colorectal tumor

b As general complications were considered: pulmonary, cardiovascular, urinary tract, infectious (other than local hepatic) and iatrogenic complications

${ }^{c}$ Patients with one or more individual vascular changes

d Vasodilatation or congestion

\section{Evolution of RNH Within Time}

Fifteen of 82 patients $(18 \%)$ with vascular changes of the nontumoral liver at first hepatectomy underwent repeat liver surgery. This included 2 of 22 patients (9\%) with $\mathrm{RNH}$ at first hepatectomy.

RNH was replaced by $\mathrm{HCN}$ at second hepatectomy in both patients following interruption of oxaliplatin and subsequent treatment with irinotecan. These patients received 11 and 12 cycles of irinotecan-based chemotherapy between both hepatectomies, respectively. No new cases of RNH were found at repeat hepatectomy in the remaining cases. 
FIG. 2 Example of regenerative nodular hyperplasia. Nodules of hyperplastic hepatocytes replace the normal liver parenchyma and are surrounded by atrophic plates without evidence of fibrosis (note the hemorrhagic changes close to atrophic plates). a Gordon and Sweet stain $(\times 20)$; b Hematoxylin-eosin stain $(\times 10)$; c Picrosirius stain $(\times 20)$; d Picrosirius stain $(\times 10)$
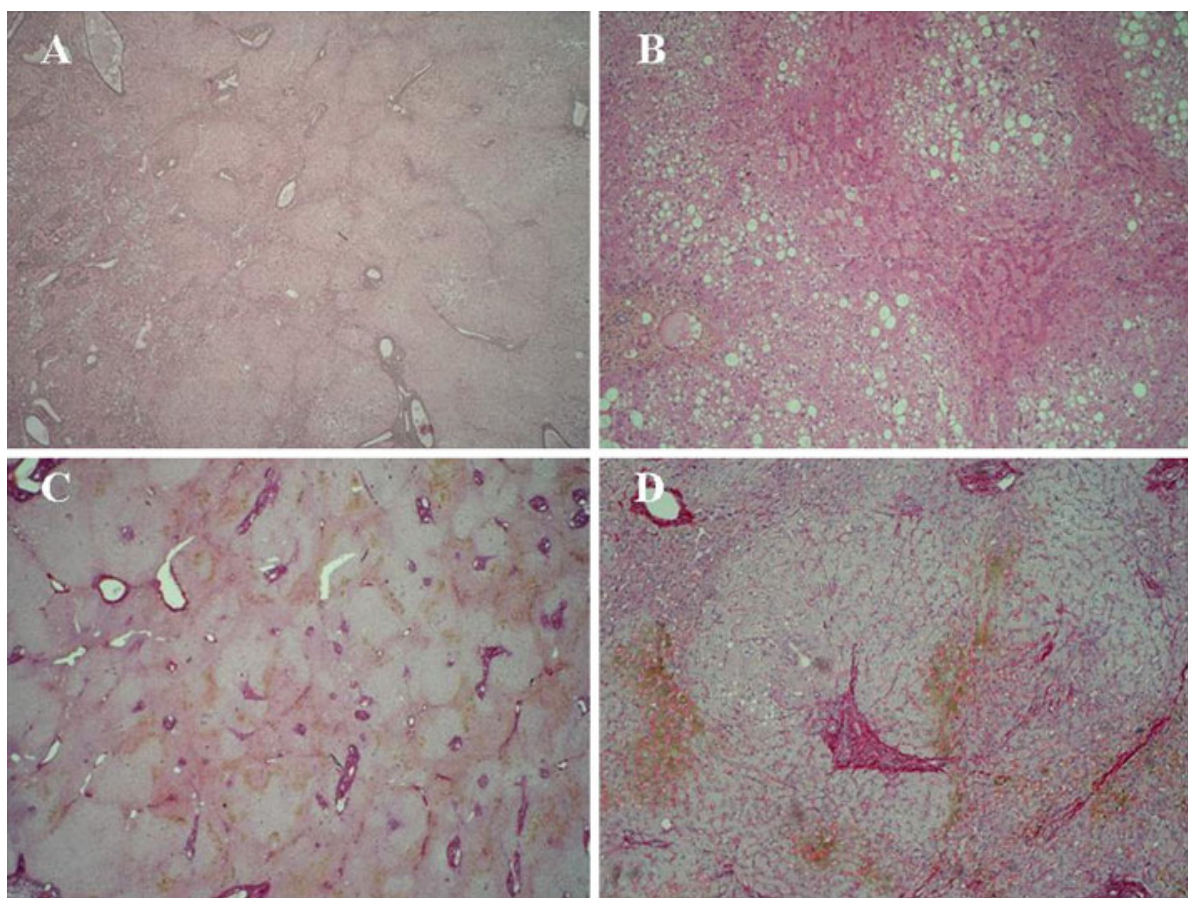

TABLE 3 Characteristics of patients with and without RNH

\begin{tabular}{|c|c|c|c|}
\hline & $\begin{array}{l}\text { No RNH } \\
(\mathrm{N}=124)\end{array}$ & $\begin{array}{l}\mathrm{RNH} \\
(\mathrm{N}=22)\end{array}$ & $P$ \\
\hline \multicolumn{4}{|l|}{ Patients } \\
\hline Mean age \pm SD (yr) & $59.1 \pm 9.9$ & $59.1 \pm 7.6$ & 0.99 \\
\hline Male/female ratio & $\begin{array}{l}73(59 \%) / \\
51(41 \%)\end{array}$ & $\begin{array}{l}12(55 \%) / \\
10(46 \%)\end{array}$ & 0.71 \\
\hline $\begin{array}{l}\text { Mean body mass } \\
\text { index } \pm \mathrm{SD}\left(\mathrm{kg} / \mathrm{m}^{2}\right)\end{array}$ & $24.0 \pm 3.5$ & $24.4 \pm 4$ & 0.6 \\
\hline Diabetes mellitus & $6(5 \%)$ & $2(10 \%)$ & 0.43 \\
\hline \multicolumn{4}{|l|}{ Liver metastases diagnosis } \\
\hline Synchronous $^{\mathrm{a}}$ & $91(73 \%)$ & $20(91 \%)$ & 0.08 \\
\hline \multicolumn{4}{|l|}{ Number } \\
\hline$\leq 3$ & $58(50 \%)$ & $4(22 \%)$ & $\mathbf{0 . 0 3}$ \\
\hline$>3$ & $59(50 \%)$ & $14(78 \%)$ & \\
\hline $\begin{array}{l}\text { Mean maximum } \\
\quad \text { size } \pm \mathrm{SD}(\mathrm{mm})\end{array}$ & $44.5 \pm 28.4$ & $49 \pm 30.2$ & 0.52 \\
\hline Bilobar & $84(68 \%)$ & $18(82 \%)$ & 0.19 \\
\hline \multicolumn{4}{|l|}{ Preoperative chemotherapy } \\
\hline Chronotherapy & $53(43 \%)$ & $6(27 \%)$ & 0.16 \\
\hline $\begin{array}{l}\text { Mean number of } \\
\text { cycles } \pm \text { SD }\end{array}$ & $8.8 \pm 2.8$ & $9.1 \pm 2.7$ & 0.55 \\
\hline$\leq 9$ & $75(63 \%)$ & $12(55 \%)$ & 0.45 \\
\hline$>9$ & $44(37 \%)$ & $10(46 \%)$ & \\
\hline \multicolumn{4}{|l|}{ Regimen } \\
\hline $\begin{array}{l}\text { 5-FU/LV and } \\
\text { oxaliplatin }\end{array}$ & $72(58 \%)$ & $20(91 \%)$ & 0.003 \\
\hline Other & $52(42 \%)$ & $2(9 \%)$ & \\
\hline \multicolumn{4}{|c|}{ Preoperative biochemical variables } \\
\hline $\begin{array}{l}\text { Mean ICG- } \\
\quad \text { R15 } \pm \text { SD }(\%)\end{array}$ & $15 \pm 7.3$ & $13 \pm 5.7$ & 0.35 \\
\hline
\end{tabular}

TABLE 3 continued

\begin{tabular}{|c|c|c|c|}
\hline & $\begin{array}{l}\text { No RNH } \\
(\mathrm{N}=124)\end{array}$ & $\begin{array}{l}\mathrm{RNH} \\
(\mathrm{N}=22)\end{array}$ & $P$ \\
\hline $\begin{array}{l}\text { Mean hemoglobin } \\
\text { level } \pm \mathrm{SD}(\mathrm{g} / \mathrm{dL})\end{array}$ & $12.3 \pm 1.5$ & $11.9 \pm 1.5$ & 0.27 \\
\hline $\begin{array}{l}\text { Mean platelet } \\
\text { count } \pm \text { SD }\left(10^{3} / \mu \mathrm{L}\right)\end{array}$ & $217.8 \pm 74.7$ & $158.7 \pm 63.3$ & 0.001 \\
\hline$\leq 150$ & $19(17 \%)$ & $10(48 \%)$ & 0.002 \\
\hline$>150$ & $92(83 \%)$ & $11(52 \%)$ & \\
\hline $\begin{array}{l}\text { Mean prothrombin } \\
\text { time } \pm \text { SD }(\%)\end{array}$ & $90.2 \pm 12.2$ & $91.8 \pm 8.9$ & 0.59 \\
\hline Mean AST \pm SD $(\mathrm{U} / \mathrm{L})$ & $48 \pm 64.7$ & $58.6 \pm 36.2$ & 0.46 \\
\hline Mean ALT \pm SD $(\mathrm{U} / \mathrm{L})$ & $46.9 \pm 81$ & $60.2 \pm 49.6$ & 0.46 \\
\hline Mean AP \pm SD (U/L) & $133.6 \pm 124.7$ & $208.8 \pm 154.5$ & 0.03 \\
\hline$\leq 100$ & $52(52 \%)$ & $2(12 \%)$ & 0.002 \\
\hline$>100$ & $49(49 \%)$ & $15(88 \%)$ & \\
\hline Mean GGT $\pm \mathrm{SD}(\mathrm{U} / \mathrm{L})$ & $96.1 \pm 125.2$ & $235.2 \pm 284.8$ & $<\mathbf{0 . 0 0 1}$ \\
\hline$\leq 80$ & $75(65 \%)$ & $4(20 \%)$ & $<\mathbf{0 . 0 0 1}$ \\
\hline$>80$ & $40(35 \%)$ & $16(80 \%)$ & \\
\hline $\begin{array}{l}\text { Mean total } \\
\text { bilirubin } \pm \mathrm{SD} \\
(\mu \mathrm{mol} / \mathrm{L})\end{array}$ & $11.8 \pm 10.1$ & $15 \pm 8.5$ & 0.17 \\
\hline$\leq 15$ & $100(86 \%)$ & $14(64 \%)$ & 0.01 \\
\hline$>15$ & $16(14 \%)$ & $8(36 \%)$ & \\
\hline \multicolumn{4}{|l|}{ Hepatectomy } \\
\hline $\begin{array}{l}\text { Major resection }(\geq 3 \\
\text { segments) }\end{array}$ & $61(49 \%)$ & $12(55 \%)$ & 0.64 \\
\hline \multicolumn{4}{|l|}{ Vascular occlusion } \\
\hline No & $20(17 \%)$ & $1(5 \%)$ & 0.47 \\
\hline Total pedicular & $60(52 \%)$ & $13(62 \%)$ & \\
\hline
\end{tabular}


TABLE 3 continued

\begin{tabular}{|c|c|c|c|}
\hline & $\begin{array}{l}\text { No RNH } \\
(\mathrm{N}=124)\end{array}$ & $\begin{array}{l}\mathrm{RNH} \\
(\mathrm{N}=22)\end{array}$ & $P$ \\
\hline Vascular exclusion & $16(14 \%)$ & $4(19 \%)$ & \\
\hline Selective & $19(17 \%)$ & $3(14 \%)$ & \\
\hline Portal vein embolization & $13(11 \%)$ & $5(23 \%)$ & 0.11 \\
\hline Two-stage hepatectomy & $7(6 \%)$ & $3(14 \%)$ & 0.17 \\
\hline $\begin{array}{l}\text { Mean red blood cell } \\
\text { transfusions } \pm \text { SD } \\
\text { (units) }\end{array}$ & $1.5 \pm 2.4$ & $1.4 \pm 1.5$ & 0.9 \\
\hline No & $68(61 \%)$ & $10(48 \%)$ & 0.24 \\
\hline Yes & $43(39 \%)$ & $11(52 \%)$ & \\
\hline \multicolumn{4}{|l|}{ Postoperative outcome } \\
\hline Mortality ( $\leq 60$ days) & $1(1 \%)$ & $0(0 \%)$ & 0.67 \\
\hline Morbidity & $50(40 \%)$ & $13(59 \%)$ & 0.1 \\
\hline General complications ${ }^{\mathrm{b}}$ & $35(28 \%)$ & $8(36 \%)$ & 0.44 \\
\hline Hepatic complications & $36(29 \%)$ & $11(50 \%)$ & 0.05 \\
\hline Biliary leak & $0(0 \%)$ & $3(27 \%)$ & 0.04 \\
\hline Hemorrhage & $2(6 \%)$ & $0(0 \%)$ & \\
\hline Infected collection & $4(11 \%)$ & $1(9 \%)$ & \\
\hline Noninfected collection & $18(50 \%)$ & $3(27 \%)$ & \\
\hline Liver insufficiency $^{23}$ & $6(17 \%)$ & $2(18 \%)$ & \\
\hline Combination & $6(17 \%)$ & $2(18 \%)$ & \\
\hline Relaparotomy & $5(4 \%)$ & $0(0 \%)$ & 0.34 \\
\hline Drainage & $11(9 \%)$ & $3(14 \%)$ & 0.48 \\
\hline $\begin{array}{l}\text { Mean hospital } \\
\text { stay } \pm \text { SD (days) }\end{array}$ & $12.7 \pm 5.7$ & $13.9 \pm 7.3$ & 0.36 \\
\hline \multicolumn{4}{|l|}{ Nontumoral liver } \\
\hline Sinusoidal alterations ${ }^{c}$ & $13(11 \%)$ & $3(14 \%)$ & 0.66 \\
\hline Peliosis & $38(31 \%)$ & $7(32 \%)$ & 0.91 \\
\hline $\mathrm{HCN}$ & $30(24 \%)$ & $6(27 \%)$ & 0.77 \\
\hline
\end{tabular}

$R N H$ regenerative nodular hyperplasia, $S D$ standard deviation, $I C G-R 15$ indocyanine green retention rate at 15 minutes, AST aspartate aminotransferase, $A L T$ alanine aminotransferase, $A P$ alkaline phosphatase, GGT gamma-glutamyltransferase, $H C N$ hemorrhagic centrilobular necrosis

${ }^{a}$ Synchronous metastases were diagnosed before or within 3 months after resection of the primary colorectal tumor

b As general complications were considered: pulmonary, cardiovascular, urinary tract, infectious (other than local hepatic) and iatrogenic complications

c Vasodilatation or congestion

\section{DISCUSSION}

Although previous reports have correlated preoperative chemotherapy for CLM with increased postoperative complications, evidence for a direct relation between specific nontumoral liver lesions and postoperative morbidity remains preliminary. ${ }^{7-10,25,26}$ With the increasing use of preoperative chemotherapy, especially oxaliplatin, it is nevertheless important to know the incidence and impact of different vascular lesions on postoperative outcome and to know how these lesions can be predicted to adjust patient monitoring and to identify patients at risk of increased morbidity.

Our present study shows that RNH may occur in $15 \%$ of patients treated with preoperative chemotherapy. RNH is associated with increased hepatic morbidity and occurs most frequently in patients receiving oxaliplatin. Interestingly, its presence can be predicted preoperatively by elevated levels of GGT and total bilirubin.

The fact that RNH was related with increased postoperative hepatic morbidity was an important finding of our study. However, only a preoperative platelet count of $<150 \times 10^{3} / \mu \mathrm{L}$, major hepatectomy, two-stage hepatectomy, and intraoperative red blood cell transfusion were independent predictors of hepatic morbidity at multivariate analysis in the total study population. Major hepatectomy, two-stage hepatectomy, and intraoperative red blood cell transfusions were equally distributed between $\mathrm{RNH}$ and non-RNH patients. However, RNH patients had relatively low platelet counts compared with non-RNH patients. We may assume that a low platelet count was related to splenomegaly due to portal hypertension caused by RNH, with subsequent platelet trapping. These results all strengthen the association of RNH with increased hepatic morbidity observed in our study.

In a recent study, sinusoidal liver injury was related with increased morbidity after major hepatectomy for CLM after preoperative chemotherapy. ${ }^{10}$ Our inclusion of both minor and major hepatectomies confirms the importance of recognizing $\mathrm{RNH}$ in all patients scheduled for hepatectomy after preoperative chemotherapy treatment. Furthermore, our result was independent of the number of chemotherapy cycles.

Interestingly, we identified preoperative elevated levels of GGT and total bilirubin as predictive factors of RNH. A recent study also found that high levels of GGT predicted the presence of sinusoidal lesions. ${ }^{27}$ Surprisingly, mean ICG-R15 values, known to be more sensitive and reliable for hepatic injury, were not altered in our patients with RNH. For patients at risk for RNH, efforts should be made to reduce the risks of liver surgery. Techniques, such as portal vein embolization and two-stage hepatectomy, may be helpful to spare the highest amount of liver parenchyma as possible, thereby maximizing the chances of an uneventful postoperative course.

In relation with the increased risk of hepatic morbidity and the enlarging number of patients who undergo repeat hepatectomy with perioperative chemotherapy, it is important to consider the evolution of RNH within time. RNH may have deleterious long-term consequences related to the development of portal hypertension. One case study reported the development of RNH and portal hypertension in three patients treated with oxaliplatin that finally 
TABLE 4 Univariate and multivariate analysis of hepatic morbidity

\begin{tabular}{|c|c|c|c|c|c|c|}
\hline \multirow[t]{2}{*}{ Variable } & \multirow[t]{2}{*}{$\mathrm{N}$} & \multicolumn{2}{|c|}{ Hepatic morbidity } & \multirow[b]{2}{*}{ UV $P$} & \multirow[b]{2}{*}{ MV $P$} & \multirow[b]{2}{*}{$\mathrm{RR}(95 \% \mathrm{CI})$} \\
\hline & & Yes $(\mathrm{N}=47)$ & No $(\mathrm{N}=99)$ & & & \\
\hline \multicolumn{7}{|l|}{ Patient factors } \\
\hline \multicolumn{7}{|l|}{ Gender } \\
\hline Male & 85 & $25(53 \%)$ & $60(61 \%)$ & 0.4 & - & - \\
\hline Female & 61 & $22(47 \%)$ & $39(39 \%)$ & & & \\
\hline \multicolumn{7}{|l|}{ Age at hepatectomy (yr) } \\
\hline$\leq 60$ & 78 & $22(47 \%)$ & $56(57 \%)$ & 0.27 & - & - \\
\hline$>60$ & 68 & $25(53 \%)$ & $43(43 \%)$ & & & \\
\hline \multicolumn{7}{|l|}{ Liver metastases } \\
\hline \multicolumn{7}{|l|}{ Synchronous ${ }^{\mathrm{a}}$} \\
\hline No & 35 & $7(15 \%)$ & $28(28 \%)$ & 0.08 & NS & - \\
\hline Yes & 111 & $40(85 \%)$ & $71(72 \%)$ & & & \\
\hline \multicolumn{7}{|l|}{ Number } \\
\hline$\leq 3$ & 62 & $17(43 \%)$ & $45(47 \%)$ & 0.6 & - & - \\
\hline$>3$ & 73 & $23(58 \%)$ & $50(53 \%)$ & & & \\
\hline \multicolumn{7}{|l|}{ Maximum size (mm) } \\
\hline$\leq 30$ & 50 & $17(40 \%)$ & $33(38 \%)$ & 0.9 & - & - \\
\hline$>30$ & 79 & $26(61 \%)$ & $53(62 \%)$ & & & \\
\hline \multicolumn{7}{|l|}{ Localization } \\
\hline Unilobar & 44 & $13(28 \%)$ & $31(31 \%)$ & 0.65 & - & - \\
\hline Bilobar & 102 & $34(72 \%)$ & $68(69 \%)$ & & & \\
\hline \multicolumn{7}{|l|}{ Initial resectability } \\
\hline No & 105 & $36(77 \%)$ & $69(70 \%)$ & 0.39 & - & - \\
\hline Yes & 41 & $11(23 \%)$ & $30(30 \%)$ & & & \\
\hline \multicolumn{7}{|c|}{ Concomitant extrahepatic disease } \\
\hline No & 125 & $40(87 \%)$ & $85(86 \%)$ & 0.86 & - & - \\
\hline Yes & 20 & $6(13 \%)$ & $14(14 \%)$ & & & \\
\hline \multicolumn{7}{|l|}{ Preoperative chemotherapy } \\
\hline \multicolumn{7}{|l|}{ No. of cycles } \\
\hline$\leq 9$ & 87 & $26(57 \%)$ & $61(64 \%)$ & 0.38 & - & - \\
\hline$>9$ & 54 & $20(44 \%)$ & $34(36 \%)$ & & & \\
\hline \multicolumn{7}{|l|}{ Regimen } \\
\hline 5-FU/LV and oxaliplatin & 92 & $33(70 \%)$ & $59(60 \%)$ & 0.21 & - & - \\
\hline Other & 54 & $14(30 \%)$ & $40(40 \%)$ & & & \\
\hline \multicolumn{7}{|c|}{ Preoperative biochemical variables } \\
\hline \multicolumn{7}{|c|}{ ICG-R15 (\%) } \\
\hline$\leq 10$ & 22 & $10(35 \%)$ & $12(21 \%)$ & 0.19 & - & - \\
\hline$>10$ & 63 & $19(66 \%)$ & $44(79 \%)$ & & & \\
\hline \multicolumn{7}{|l|}{ Platelet count ${ }^{\mathrm{a}}\left(10^{3} / \mu \mathrm{L}\right)$} \\
\hline$\leq 150$ & 29 & $13(33 \%)$ & $16(17 \%)$ & 0.05 & 0.01 & $3.5(1.3-9.2)$ \\
\hline$>150$ & 103 & $27(68 \%)$ & $76(83 \%)$ & & & \\
\hline Prothrombin time $(\%)$ & & & & & & \\
\hline$\leq 90$ & 50 & $18(41 \%)$ & $32(36 \%)$ & 0.58 & - & - \\
\hline$>90$ & 83 & $26(59 \%)$ & $57(64 \%)$ & & & \\
\hline $\operatorname{AST}^{\mathrm{a}}(\mathrm{U} / \mathrm{L})$ & & & & & & \\
\hline$\leq 30$ & 63 & $16(36 \%)$ & $47(51 \%)$ & 0.10 & NS & - \\
\hline$>30$ & 75 & $29(64 \%)$ & $46(50 \%)$ & & & \\
\hline
\end{tabular}


TABLE 4 continued

\begin{tabular}{|c|c|c|c|c|c|c|}
\hline \multirow[t]{2}{*}{ Variable } & \multirow[t]{2}{*}{$\mathrm{N}$} & \multicolumn{2}{|c|}{ Hepatic morbidity } & \multirow[b]{2}{*}{ UV $P$} & \multirow[b]{2}{*}{ MV $P$} & \multirow[b]{2}{*}{$\mathrm{RR}(95 \% \mathrm{CI})$} \\
\hline & & Yes $(\mathrm{N}=47)$ & No $(\mathrm{N}=99)$ & & & \\
\hline \multicolumn{7}{|c|}{ ALT (U/L) } \\
\hline$\leq 30$ & 76 & $23(51 \%)$ & $53(57 \%)$ & 0.52 & - & - \\
\hline$>30$ & 62 & $22(49 \%)$ & $40(43 \%)$ & & & \\
\hline \multicolumn{7}{|c|}{$\mathrm{AP}(\mathrm{U} / \mathrm{L})$} \\
\hline$\leq 100$ & 54 & $19(48 \%)$ & $35(45 \%)$ & 0.79 & - & - \\
\hline$>100$ & 64 & $21(53 \%)$ & $43(55 \%)$ & & & \\
\hline \multicolumn{7}{|c|}{ GGT (U/L) } \\
\hline$\leq 80$ & 79 & $28(64 \%)$ & $51(56 \%)$ & 0.4 & - & - \\
\hline$>80$ & 56 & $16(36 \%)$ & $40(44 \%)$ & & & \\
\hline \multicolumn{7}{|c|}{ Total bilirubin $(\mu \mathrm{mol} / \mathrm{L})$} \\
\hline$\leq 15$ & 114 & $35(78 \%)$ & $79(85 \%)$ & 0.3 & - & - \\
\hline$>15$ & 24 & $10(22 \%)$ & $14(15 \%)$ & & & \\
\hline \multicolumn{7}{|c|}{ Hepatectomy } \\
\hline \multicolumn{7}{|c|}{ Major resection $^{\mathrm{a}}$ ( $\geq 3$ segments) } \\
\hline No & 73 & $17(36 \%)$ & $56(57 \%)$ & 0.02 & 0.05 & $2.6(1-6.4)$ \\
\hline Yes & 73 & $30(64 \%)$ & $43(43 \%)$ & & & \\
\hline \multicolumn{7}{|c|}{ Pedicular clamping } \\
\hline No & 43 & $10(23 \%)$ & $33(36 \%)$ & 0.12 & - & - \\
\hline Yes & 93 & $34(77 \%)$ & $59(64 \%)$ & & & \\
\hline \multicolumn{7}{|c|}{ Combined local treatment } \\
\hline No & 129 & $43(92 \%)$ & $86(87 \%)$ & 0.42 & - & - \\
\hline Yes & 17 & $4(9 \%)$ & $13(13 \%)$ & & & \\
\hline \multicolumn{7}{|c|}{ Portal vein embolization } \\
\hline No & 128 & $40(85 \%)$ & $88(89 \%)$ & 0.52 & - & - \\
\hline Yes & 18 & $7(15 \%)$ & $11(11 \%)$ & & & \\
\hline \multicolumn{7}{|c|}{ Two-stage hepatectomy ${ }^{\mathrm{a}}$} \\
\hline No & 136 & $41(87 \%)$ & $95(96 \%)$ & 0.05 & 0.03 & $5.7(1.2-27.2)$ \\
\hline Yes & 10 & $6(13 \%)$ & $4(4 \%)$ & & & \\
\hline \multicolumn{7}{|c|}{ Intraoperative $\mathrm{RBC}$ transfusion ${ }^{\mathrm{a}}$} \\
\hline No & 78 & $19(43 \%)$ & $59(67 \%)$ & 0.01 & 0.03 & $2.6(1.1-6.1)$ \\
\hline Yes & 54 & $25(57 \%)$ & $29(33 \%)$ & & & \\
\hline \multicolumn{7}{|c|}{ Nontumoral liver } \\
\hline \multicolumn{7}{|c|}{ Macrovacuolar steatosis $(\leq 30 \%)$} \\
\hline No & 134 & $44(94 \%)$ & $90(91 \%)$ & 0.58 & - & - \\
\hline Yes & 12 & $3(6 \%)$ & $9(9 \%)$ & & & \\
\hline \multicolumn{7}{|l|}{ Fibrosis } \\
\hline No & 77 & $28(60 \%)$ & $49(50 \%)$ & 0.25 & - & - \\
\hline Yes & 69 & $19(40 \%)$ & $50(51 \%)$ & & & \\
\hline \multicolumn{7}{|c|}{ Sinusoidal alterations } \\
\hline No & 130 & $43(92 \%)$ & $87(88 \%)$ & 0.51 & - & - \\
\hline Yes & 16 & $4(9 \%)$ & $12(12 \%)$ & & & \\
\hline Peliosis & & & & & & \\
\hline No & 101 & $31(66 \%)$ & $70(71 \%)$ & 0.56 & - & - \\
\hline Yes & 45 & $16(34 \%)$ & $29(29 \%)$ & & & \\
\hline $\mathrm{HCN}$ & & & & & & \\
\hline No & 109 & $37(79 \%)$ & $72(74 \%)$ & 0.49 & - & - \\
\hline Yes & 36 & $10(21 \%)$ & $26(27 \%)$ & & & \\
\hline
\end{tabular}


TABLE 4 continued

\begin{tabular}{|c|c|c|c|c|c|c|}
\hline \multirow[t]{2}{*}{ Variable } & \multirow[t]{2}{*}{$\mathrm{N}$} & \multicolumn{2}{|c|}{ Hepatic morbidity } & \multirow[b]{2}{*}{ UV $P$} & \multirow[b]{2}{*}{ MV $P$} & \multirow[b]{2}{*}{$\operatorname{RR}(95 \% \mathrm{CI})$} \\
\hline & & Yes $(N=47)$ & No $(\mathrm{N}=99)$ & & & \\
\hline \multicolumn{7}{|l|}{$\mathrm{RNH}^{\mathrm{a}}$} \\
\hline No & 124 & $36(77 \%)$ & $88(89 \%)$ & 0.05 & NS & - \\
\hline Yes & 22 & $11(23 \%)$ & $11(11 \%)$ & & & \\
\hline
\end{tabular}

$U V$ univariate, $M V$ multivariate, $R R$ risk ratio, $C I$ confidence interval, $N S$ not significant, 5-FU/LV 5-fluorouracil/leucovorin, $I C G-R 15$ indocyanine green retention rate at 15 minutes, $A S T$ aspartate aminotransferase, $A L T$ alanine aminotransferase, $A P$ alkaline phosphatase, $G G T$ gamma-glutamyltransferase, $R B C$ red blood cell, $H C N$ hemorrhagic centrilobular necrosis, $R N H$ regenerative nodular hyperplasia

${ }^{a}$ Variables entered in Cox regression model

contraindicated curative liver surgery. ${ }^{28}$ Recently, the development of portal hypertension in patients with RNH with deleterious postoperative complications and even death was reported by another group. ${ }^{29}$ Other reports on $\mathrm{RNH}$ as a result of preoperative chemotherapy are rare. ${ }^{30}$ When we evaluated the evolution of vascular lesions in patients that underwent repeat hepatectomy, previously diagnosed RNH was replaced by $\mathrm{HCN}$ in two patients. Because RNH is distributed throughout the liver in a regular pattern, sample variation is unlikely to cause the absence of RNH at subsequent hepatectomies. ${ }^{31}$ Furthermore, all nontumoral liver specimens were evaluated by the same hepatobiliary pathologist. The natural history of RNH remains largely unknown. ${ }^{28}$ However, because it is a noncirrhotic liver disease without fibrosis, RNH can theoretically regress, as was demonstrated in our study. ${ }^{27}$

Interestingly, in both patients in whom RNH disappeared, oxaliplatin was stopped and irinotecan was administered before the second hepatectomy. This may suggest that irinotecan may be a good alternative of oxaliplatin to treat these patients. Previously, RNH had already been associated with the use of oxaliplatin. ${ }^{4}$ Recently, different authors have suggested a protective effect of bevacizumab on the development of vascular toxicity. ${ }^{32-34}$ Therefore, its addition to conventional chemotherapy may reduce the risk of RNH and associated morbidity. However, this issue lies beyond the scope of the present study and needs further evaluation. Conclusions on the evolution of vascular lesions other than RNH into less or more severe types at repeat hepatectomy are difficult because of their irregular distribution throughout the liver with the subsequent risk of sample variation.

Our study represents a selected patient group that received only one line of chemotherapy. By this way, we were able to correlate $\mathrm{RNH}$ with different chemotherapy regimens most accurately. However, with the large amount of patients receiving multiple chemotherapy regimens before surgery, RNH may be even more frequent in daily practice. The potential negative effect of portal hypertension related to RNH on patient outcome should not be underestimated.

A final interesting remark of our study is that we observed only one patient with steatohepatitis, who received oxaliplatin before hepatectomy. Previous large series have associated steatohepatitis mainly with irinotecan, one of whom even found that steatohepatitis was related with an increased 90-day mortality rate. ${ }^{7,14}$ The low incidence of obese patients and patients with diabetes probably is one of the reasons for the low frequency of steatohepatitis in our current study. The precise causes and consequences of this entity should nevertheless be investigated more extensively.

\section{CONCLUSIONS}

An increasing number of patients with CLM currently receive oxaliplatin-based chemotherapy, including adjuvant treatment after stage III colon cancer, induction therapy to convert extensive metastases to resectability, or perioperative treatment in patients with resectable metastases. ${ }^{1,3,35}$ RNH may occur in one of five patients, with an increased risk of postoperative morbidity after hepatectomy. Elevated serum GGT and bilirubin are useful markers to detect RNH that does not contraindicate hepatic resection. Clinical recommendations regarding preoperative chemotherapy treatment based on these results should be evaluated further, taking into account the availability and consequences of new biological agents.

\section{CONFLICT OF INTEREST None.}

OPEN ACCESS This article is distributed under the terms of the Creative Commons Attribution Noncommercial License which permits any noncommercial use, distribution, and reproduction in any medium, provided the original author(s) and source are credited.

\section{REFERENCES}

1. Adam R, Delvart V, Pascal G, et al. Rescue surgery for unresectable colorectal liver metastases downstaged by 
chemotherapy: a model to predict long-term survival. Ann Surg. 2004;240:644-57.

2. Tanaka K, Adam R, Shimada H, Azoulay D, Lévi F, Bismuth H. Role of neoadjuvant chemotherapy in the treatment of multiple colorectal metastases to the liver. Br J Surg. 2003;90:963-9.

3. Nordlinger B, Sorbye H, Glimelius B, et al. Perioperative chemotherapy with FOLFOX4 and surgery versus surgery alone for resectable liver metastases from colorectal cancer (EORTC Intergroup trial 40983): a randomised controlled trial. Lancet. 2008;371:1007-16.

4. Rubbia-Brandt L, Audard V, Sartoretti P, et al. Severe hepatic sinusoidal obstruction associated with oxaliplatin-based chemotherapy in patients with metastatic colorectal cancer. Ann Oncol. 2004; 15:460-6.

5. Fernandez FG, Ritter J, Goodwin JW, Linehan DC, Hawkins WG, Strasberg SM. Effect of steatohepatitis associated with irinotecan or oxaliplatin pretreatment on resectability of hepatic colorectal metastases. J Am Coll Surg. 2005;200:845-53.

6. Karoui M, Penna C, Amin-Hashem M, et al. Influence of preoperative chemotherapy on the risk of major hepatectomy for colorectal liver metastases. Ann Surg. 2006;243:1-7.

7. Vauthey JN, Pawlik TM, Ribero D, et al. Chemotherapy regimen predicts steatohepatitis and an increase in 90-day mortality after surgery for hepatic colorectal metastases. J Clin Oncol. 2006;24:2065-72.

8. Aloia T, Sebagh M, Plasse M, et al. Liver histology and surgical outcomes after preoperative chemotherapy with fluorouracil plus oxaliplatin in colorectal cancer liver metastases. J Clin Oncol. 2006;24:4983-90.

9. Mehta NN, Ravikumar R, Coldham CA, et al. Effect of preoperative chemotherapy on liver resection for colorectal liver metastases. Eur J Surg Oncol. 2008;34:782-6.

10. Nakano H, Oussoultzoglou E, Rosso E, et al. Sinusoidal injury increases morbidity after major hepatectomy in patients with colorectal liver metastases receiving preoperative chemotherapy. Ann Surg. 2008;247:118-24.

11. Kandutsch S, Klinger M, Hacker S, Wrba F, Gruenberger B, Gruenberger T. Patterns of hepatotoxicity after chemotherapy for colorectal cancer liver metastases. Eur J Surg Oncol. 2008;34:1231-6.

12. Parikh AA, Gentner B, Wu TT, Curley SA, Ellis LM, Vauthey JN. Perioperative complications in patients undergoing major liver resection with or without neoadjuvant chemotherapy. $J$ Gastrointest Surg. 2003;7:1082-8.

13. Hewes JC, Dighe S, Morris RW, Hutchins RR, Bhattacharya S, Davidson BR. Preoperative chemotherapy and the outcome of liver resection for colorectal metastases. World $J$ Surg. 2007;31:353-64.

14. Pawlik TM, Olino K, Gleisner AL, Torbenson M, Schulick R, Choti MA. Preoperative chemotherapy for colorectal liver metastases: impact on hepatic histology and postoperative outcome. J Gastrointest Surg. 2007;11:860-8.

15. Scoggins CR, Campbell ML, Landry CS, Slomiany BA, Woodall $\mathrm{CE}$, McMasters KM, et al. Preoperative chemotherapy does not increase morbidity or mortality of hepatic resection for colorectal cancer metastases. Ann Surg Oncol. 2009;16:35-41.

16. Yan TD, Lian KQ, Chang D, Morris DL. Management of intrahepatic recurrence after curative treatment of colorectal liver metastases. Br J Surg. 2006;93:854-9.

17. Adam R, Bismuth H, Castaing D, et al. Repeat hepatectomy for colorectal liver metastases. Ann Surg. 1997;225:51-62.

18. Bozetti F, Doci R, Bignami P, Morabito A, Gennari L. Patterns of failure following surgical resection of colorectal cancer liver metastases. Ann Surg. 1987;205:264-70.
19. Adam R, Laurent A, Azoulay D, Castaing D, Bismuth H. Twostage hepatectomy: a planned strategy to treat irresectable liver tumors. Ann Surg. 2000;232:777-85.

20. Azoulay D, Castaing D, Smail A, et al. Resection of nonresectable liver metastases from colorectal cancer after percutaneous portal vein embolization. Ann Surg. 2000;231:480-6.

21. Kornprat P, Jarnagin WR, DeMatteo RP, Fong Y, Blumgart LH, D'Angelica M. Role of intraoperative thermoablation combined with resection in the treatment of hepatic metastasis from colorectal cancer. Arch Surg. 2007;142:1087-92.

22. Dindo D, Demartines N, Clavien PA. Classification of surgical complications: a new proposal with evaluation in a cohort of 6336 patients and results of a survey. Ann Surg. 2004;240:205-13.

23. Balzan S, Belghiti J, Farges O, Ogata S, Sauvanet A, Delefosse D, et al. The "50-50 criteria" on postoperative day 5: an accurate predictor of liver failure and death after hepatectomy. Ann Surg. 2005;242:824-9.

24. Lévi F, Zidani R, Brienza S, et al. A multicenter evaluation of intensified, ambulatory, chronomodulated chemotherapy with oxaliplatin, 5-fluorouracil, and leucovorin as initial treatment of patients with metastatic colorectal carcinoma. International Organization for Cancer Chronotherapy. Cancer. 1999;85: $2532-40$

25. Zorzi D, Laurent A, Pawlik TM, Lauwers GY, Vauthey JN, Abdalla EK. Chemotherapy-associated hepatotoxicity and surgery for colorectal liver metastases. Br J Surg. 2007;94:274-86.

26. Bartlett DL, Berlin J, Lauwers GY, Messersmith WA, Petrelli NJ, Venook AP. Chemotherapy and regional therapy of hepatic colorectal metastases: expert consensus statement. Ann Surg Oncol. 2006;13:1284-92.

27. Brouquet A, Benoist S, Julie C, Penna C, Beauchet A, Rougier P, et al. Risk factors for chemotherapy-associated liver injuries: a multivariate analysis of a group of 146 patients with colorectal metastases. Surgery. 2009;145:362-71.

28. Hubert C, Sempoux C, Horsmans Y, et al. Nodular regenerative hyperplasia: a deleterious consequence of chemotherapy for colorectal liver metastases? Liver Int. 2007;27:938-43.

29. van den Broek MA, Olde Damink SW, Driessen A, Dejong CH, Bemelmans MH. Nodular regenerative hyperplasia secondary to neoadjuvant chemotherapy for colorectal liver metastases. Case Report Med. 2009:457975.

30. Rosen AA, Iseri O, Fishbein G, Knodell RG. Nodular regenerative hyperplasia: a cause of ascites and hepatomegaly after chemotherapy for leukemia. Am J Gastroenterol. 1991;86:86-8.

31. Wanless IR. Micronodular transformation (nodular regenerative hyperplasia) of the liver: a report of 64 cases among 2,500 autopsies and a new classification of benign hepatocellular nodules. Hepatology. 1990;11:787-97.

32. Rubbia-Brandt L, Lauwers GY, Wang H, et al. Sinusoidal obstruction syndrome and nodular regenerative hyperplasia are frequent oxaliplatin-associated liver lesions and partially prevented by bevacizumab in patients with hepatic colorectal metastasis. Histopathology. 2010;56:430-9.

33. Ribero D, Wang H, Donadon M, et al. Bevacizumab improves pathologic response and protects against hepatic injury in patients treated with oxaliplatin-based chemotherapy for colorectal liver metastases. Cancer. 2007;110:2761-7.

34. Kishi Y, Zorzi D, Contreras CM, et al. Extended preoperative chemotherapy does not improve pathologic response and increases postoperative liver insufficiency after hepatic resection for colorectal liver metastases. Ann Surg Oncol. 2010 (in press).

35. André T, Boni C, Mounedji-Boudiaf L, et al. Oxaliplatin, fluorouracil, and leucovorin as adjuvant treatment for colon cancer. N Engl J Med. 2004;350:2343-51. 